\title{
HOSPITAL BASED CROSS SECTIONAL STUDY OF HERPES ZOSTER IN
}

\section{CHILDHOOD}

Murugan S1, Adikrishnan S2, Trishna Vaishali M33, Krishnakanth M4, Sudha R5, Anandan S6, Mahalakshmi $\mathrm{V}^{7}$

\section{HOW TO CITE THIS ARTICLE:}

Murugan S, Adikrishnan S, Trishna Vaishali M, Krishnakanth M, Sudha R, Anandan S, Mahalakshmi V. "Hospital Based Cross Sectional Study of Herpes Zoster in Childhood". Journal of Evolution of Medical and Dental Sciences 2015; Vol. 4, Issue 84, October 19; Page: 14699-14701, DOI: 10.14260/jemds/2015/2089

ABSTRACT: Herpes Zoster is caused by the reactivation of the varicella zoster virus, emerging from latency in the dorsal root ganglion. Herpes zoster in childhood is a less reported entity.

KEYWORDS: Herpes Zoster, Childhood, Immuno Suppression.

AIM OF THE STUDY: The present study was carried out to study the evolution and course of zoster in paediatric age group.

MATERIAL AND METHODS: Children clinically diagnosed with Herpes Zoster aged between 4-15 years, who attended the Dermatology OPD at Sri Ramachandra Medical College Hospital between April 2014 to April 2015 were enrolled for the study.

OBSERVATION \& RESULTS: 20 Children with Herpes zoster, were enrolled in the study. Distribution was equal in male and female children. Thoracic dermatomal involvement seen in (7/20) pts. Ophthalmic division of Trigeminal nerve was involved in $(5 / 20)$ patients. Lumbosacral dermatome was involved in (6/20) patients. Cervical dermatome was involved in 1 patient. The right side involvement was seen in (15/20) pts. Left sided l involvement was seen in (5/20) pts. Recurrent Herpes Zoster was seen in 1 patient. Disseminated herpes zoster was seen in 2 patients. Predominantly vesicular in (16/20) pts. Bullous lesions were seen in 4 patients. 14 pts belonged to the lower socioeconomic group.

CONCLUSION: Herpes zoster occurs more commonly after varicella infection than after varicella vaccination. The younger the child is when he or she has varicella the greater the likelihood that zoster will develop in childhood or early adulthood.

\begin{tabular}{|c|c|c|}
\hline DERMATOME & LEFT SIDE & RIGHT SIDE \\
\hline Trigeminal- opth. & 3 & 3 \\
\hline Cervical & & 1 \\
\hline Thoracic & 1 & 6 \\
\hline Lumbar & 5 & 1 \\
\hline Sacral & 0 & 0 \\
\hline
\end{tabular}

Table 1: Dermatomal Distribution 


\section{ORIGINAL ARTICLE}

\begin{tabular}{|c|c|c|c|}
\hline No. & Vesicles & Bullous lesions & Disseminated Zoster \\
\hline 20 & 16 & 2 & 2 \\
\hline \multicolumn{3}{|c|}{ Lesion Morphology } \\
\hline
\end{tabular}

\begin{tabular}{|c|c|c|}
\hline No. & HIV SEROPOSITIVE & MALIGNANCY/ CHEMO. PTS \\
\hline 20 & 1 & 1 \\
\hline \multicolumn{3}{|c|}{ ImmunoSuppression } \\
\hline
\end{tabular}

DISCUSSION: Herpes zoster is caused by the reactivation of Varicella zoster virus, emerging from the period of latency in the dorsal root ganglion. Herpes zoster usually occurs after the $4^{\text {th }}$ decade of life or later, following dip in the antibody titres developed after attack of Varicella in the earlier years.[1] Childhood herpes zoster is a less reported entity. Herpes zoster is uncommon in children younger than 10 years of age. The younger the child is when he or she has Varicella, greater the likelihood that zoster will develop in childhood or early adulthood. Incidence among general population was 0-30\%.

Herpes zoster in infancy and early childhood was seen in 10 children who were asymptomatic at birth.[2] Observed risk of zoster after maternal Varicella in 13 \& 24weeks and 25 \& 36weeks was $0.8 \%$ \& $1.7 \%$ respectively.

Herpes zoster may also result from vaccination for varicella. Rash may be significantly lower in vaccinated patients because of attenuated Varicella strain. Positive History of preceding varicella was recorded in 9/20) patients. ${ }^{[3]}$ Herpes zoster is more common in cervical and sacral dermatome. In adults it is more common in thoracic and upper lumbar dermatome. In the present study, thoracic dermatome was the commonest dermatome (7/20) affected, followed by ophthalmic division of trigeminal nerve in $(5 / 20)$ pts. Cervical dermatome was involved in only 1 patient. Right sided involvement was seen in (15/20) pts. studied.[4] Contrastingly left side was involved in only (5/20) pts. Disseminated herpes zoster was seen in 2 patients. Both were immune suppressed, one child being HIV Positive, while the other child was on chemotherapy for Leukemia. Recurrent zoster was also seen in the HIV positive patient. ${ }^{[5,6]}$ Morphology of the lesions were predominantly vesicular in $(16 / 20)$ pts. Bullous lesions were seen in only 2 patients.

This condition needs to be studied in greater detail and the patients followed up into their adulthood to look for recurrences or sequelae along with any newer virological techniques which have evolved.

\section{REFERENCES:}

1. Prabhu S, Sripathi H, Gupta S, Prabhu M. Childhood herpes zoster: A clustering of ten cases. Ind J Dermatol. 2009; 54(1):62-64. doi:10.4103/0019-5154.48991.

2. Kurlan JG, Connelly BL, Lucky AW. Herpes zoster in the first year of life following postnatal exposure to Varicella-zoster virus: Four case reports and a review of infantile herpes zoster. Arch Dermatol. 2004; 140:1268-72. [PubMed].

3. Janniger CK, Driano NA, Zoster E-medicine article. Available from http://www.emedicine.com/ped/topic996.htm. [Last accessed on 2007 Jan 16].

4. Kakourou T, Theodoridou M, Mostrou G, Syriopoulou V, Papadogeorgaki H, Constantopoulos A. Herpes zoster in children. J Am Acad Dermatol. 1998; 39:207-10. [PubMed]. 


\section{ORIGINAL ARTICLE}

5. Bhushan P, Sardana K, Mahajan S. Dermatomal vesicular eruption in an asymptomatic infant. Dermatol Online J. 2005; 11:26. [PubMed].

6. Solomon AR. New diagnostic tests for herpes simplex and varicella zoster infection. J Am Acad Dermatol. 1988; 18:218-21. [PubMed].

\section{AUTHORS:}

1. Murugan S,

2. Adikrishnan $\mathrm{S}$.

3. Trishna Vaishali M.

4. Krishnakanth M.

5. Sudha R.

6. Anandan S.

7. Mahalakshmi V.

\section{PARTICULARS OF CONTRIBUTORS:}

1. Professor, Department of Dermatology, Sri Ramachandra Medical College \& Research Institute, Chennai.

2. Associate Professor, Department of Dermatology, Sri Ramachandra Medical College \& Research Institute, Chennai.

3. Junior Resident, Department of Dermatology, Sri Ramachandra Medical College \& Research Institute, Chennai.

4. Associate Professor, Department of Dermatology, Sri Ramachandra Medical College \& Research Institute, Chennai.

FINANCIAL OR OTHER COMPETING INTERESTS: None
5. Professor, Department of Dermatology, Sri Ramachandra Medical College \& Research Institute, Chennai.

6. Professor, Department of Dermatology, Sri Ramachandra Medical College \& Research Institute, Chennai.

7. Professor, Department of Dermatology, Sri Ramachandra Medical College \& Research Institute, Chennai.

\section{NAME ADDRESS EMAIL ID OF THE CORRESPONDING AUTHOR:}

Dr. Murugan S,

Plot No. 600, New No. 5,

$6^{\text {th }}$ Street, Annanagar,

West Extension,

Chennai-101.

E-mail: murug1972@gmail.com

Date of Submission: 30/09/2015.

Date of Peer Review: 01/10/2015.

Date of Acceptance: 09/10/2015.

Date of Publishing: 17/10/2015. 